\title{
Comparative Growth Analysis and Fruit Quality of Two Varieties of Tomato under Hand Weeding and Pendimethalin Herbicide
}

\author{
B.U. Olayinka, O.O. Esan, I.O. Anwo and E.O. Etejere
}

Received: $6^{\text {th }}$ February 2017 / Accepted: $13^{\text {th }}$ June 2017

\begin{abstract}
Tomato is an important vegetable crop having high nutritional value. Different agronomical practices have been used to increase its quality. Hence, field experiments were carried out to evaluate the influence of five weed control methods (Pendimethalin at 4 lha ${ }^{-1}$, Pendimethalin at 4 lha ${ }^{-1}+$ one hand weeding at 6 WAT, two hand weeding at 3 and 6 WAT, weed free and weedy check) on the biological productivity and nutritional compositions of two varieties of tomato (Roma V.F. and Tropimech). The weed control methods were arranged following randomized complete block (RCB) design in split-plot arrangement. The results showed that out of the fourteen weed species encountered six weed species: Euphorbia heterophylla, Tridax procumbens, Phyllantus amarus, Tithonia diversifolia, Gomphrena celosioides and Ageratum conyzoides were found to be preponderant. Pendimethalin at 4lha ${ }^{-1}+$ one hand weeding at 6 WAT and two hand weeding at 3 and 6 WAT showed better weed reduction (53-68\%), when compared to sole application of Pendimethalin at 4lha ${ }^{-1}(32-41 \%)$. The weed free check was the most effective in controlling weeds (96-99\%). Growth attributes such as plant height, number of leaves, leaf area, and aboveground dry weight, relative growth rate and net assimilation rate, the number of fruit per plant and harvest index were significantly enhanced in all the weed control methods compared to the weedy check. Higher values of the afore mentioned growth attributes were significantly higher under Pendimethalin at 4 lha $\mathrm{l}^{-1}+$ one hand weeding at 6 WAT when compared to other weed control treatments. The biochemical constituents such as vitamin $C$, lycopene and $\beta$-carotene and all the proximate composition except fibre were significantly higher in sole Pendimethalin at 4lha and $^{-1}$ Pendimethalin at 4lha ${ }^{-1}+$ one hand weeding 6 WAT than other weed control methods. Growth and yield were higher in variety Roma V.F. than Tropimech, while biochemical constituents were found to be higher in Tropimech than Roma V.F. Pendimetalin at 4lha ${ }^{-1}+$ one hand weeding 6 WAT was found to be effective in weed suppression with positive influence on the biological productivity and nutritional compositions of the two studied varieties.
\end{abstract}

Keywords: Biological productivity, yield, lycopene, and $\beta$-carotene, vitamin $C$, weed control

\section{INTRODUCTION}

Tomato is one of the popular and widely grown vegetable crops in Nigeria. It is a nutritive crop ranking next to potato in world's vegetable production (Tamana and Ijaz, 2014). Nigeria is ranked the second largest producer of tomato in Africa and $13^{\text {th }}$ in the world (FAO, 2011). The total production in Nigeria is estimated as one million hectares of land producing 1.701 million tonnes per annum with average of 2030 tons /hectare. The per-hectare production of tomato is low in our country as compared to top ten largest producing countries in the world such as China, India USA, Spain, Egypt Turkey Iran, Italy, Brazil and Mexico (Agriexchange, 2011). The productivity of tomato is hindered by an array of factors among which weeds are 
the most significant in terms of reduction in yield, quality and value of the crop (Tamana and Ijaz, 2014).

Weeds reduce crop yield by competing for space, light, water and nutrient. They also weakened crop stand and reduce harvesting efficiency (Abbasi et al., 2013). Some weeds also serve as alternative hosts for pest and diseases that affect crop growth (Tesfaye et al., 2015). Marana et al. (1986) estimated that critical period of weed competition in tomato is to be $30-40$ days after sowing. Therefore, it is recommended that weeds should be removed for 40-50 days after sowing. Percentage yield loss in tomato as a result of weed infestation could range from 40 to $95 \%$ (Adigun, 2000; Madueke et al., 2012). The variation in this yield loss depends on factors such as type and density of weeds, competitive ability of the crop and the agroecology of the particular area where the research was carried out. The weed control methods practiced in tomato production include, cultural, mechanical, chemical and integrated weed management (Ashton and Monaco, 1991), and integrated weed management has been found to be more efficient.

Tomato fruit has been known to be a good source of ascorbic acid, lycopene and $\beta$ carotene. These compounds have been shown to act as powerful antioxidant in human body. A diet containing a moderate amount of these antioxidants has been associated with the prevention of cardiovascular diseases and cancer of the prostate and gastrointestinal tract (Gann et al., 1999; Agarwal and Rao, 2000). Many experts have identified increasing levels of dietary lycopene carotene and ascorbic acid through the consumption of fresh tomatoes and tomato products (Tonucci et al., 1995; Giovannucci, 1999). Numerous investigations had been carried out with the aim of increasing these antioxidants in tomato via techniques such as influence of genotype, agricultural practices, nutrient interaction, temperature and irrigation practices (Abushita et al., 2000; Binoy et al.,
2004). However, information on the effect of herbicide and hand weeding on the fruit quality of tomato that are the most common methods used for weed suppression in southern Guinea savanna zone of Nigeria is scanty. Hence, the present study was carried out to investigate the effect of using hand weeding, herbicide and hand weeding plus herbicide on weed suppression, biological productivity and fruit quality of two varieties of tomato.

\section{MATERIALS AND METHODS}

\section{Study Site}

The present investigation was carried out in two different locations at the Botanical Garden of University of Ilorin, Ilorin, Nigeria between September and December 2015. Two varieties of tomato (Solanum lycopersicum Millvar. Roma V.F. and Tropimech) were used for the study. The seeds were collected from the Kwara State Ministry of Agriculture. The textural soil of the experimental site was sandy-loam with low organic matter $(0.92 \%)$, moderately low in available nitrogen (0.10) and neutral $\mathrm{pH}(6.6)$.

\section{Experimental Layout and Treatment Details}

The experiment was arranged in split plot design with tree replications. The two varieties of tomato were assigned to main plots while different weed control methods were assigned to the subplots. Each subplot that was $1 \mathrm{~m}$ by $1 \mathrm{~m}$, was separated by $0.5 \mathrm{~m}$ unplanted areas. Plants were set in single row spaced $0.3 \mathrm{~m}$ apart. Plot size was $27 \mathrm{~m} \mathrm{x} 4 \mathrm{~m}$. There were five weed control treatments. $\mathrm{T}_{1}=$ Pendimethalin [ N-(1-ethylpropyl)-3, 4-dimethly 2, 6-dinitrobenzenzamine] was applied as sole at 4 $1 \mathrm{lha}^{-1} ; \mathrm{T}_{2}=$ Pendimethalin [ N-(1-ethylpropyl)-3, 4-dimethly 2,6 dinitrobenzenzamine] was applied at $4 \mathrm{hha}^{-1}+$ one hand weeding at 6 weeks after transplanting (WAT); $\mathrm{T}_{3}=$ Two hand weeding at 3 and $6 \mathrm{WAT}_{4}=$ weed free check (weeds were manually removed throughout the 
period of the experiment); $\mathrm{T}_{5}=$ weedy check (weed infested plot or no weeding was carried out throughout the period of investigation). The Pendimethalin herbicide was applied at pretransplanting time (a week before transplanting) using a knapsack sprayer calibrated to deliver a volume at $250 \mathrm{lha}^{-1}$. Two varieties were raised in the nursery beds for four weeks. Then, healthy seedlings were transplanted to the field second week of September, 2015.

\section{Data Collection}

\section{(a) Weed and crop}

Weeds species encountered were identified using the Hand Book of West African Weeds (Akobundu and Agyakwa, 1987). Weed counts were made using $0.5 \mathrm{~m} \times 0.5 \mathrm{~m}$ quadrat placed randomly within each experimental unit. Weed biomass was determined by clipping the aboveground tissues in each experimental unit from randomly selected areas of $0.5 \mathrm{~m}$ by $0.5 \mathrm{~m}$ quadrat in each plot. The harvested weeds were oven-dried at 80 for 24 hours and biomass was determined using electronic balance MP 101 with precision of $0.1 \mathrm{~g}$. Parameters such as weed control efficiency and weed index were also estimated according to the formula of Gill and Kumar (1969) as shown below:

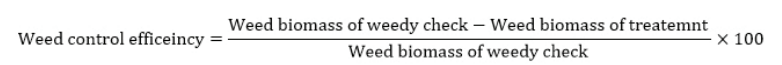

Growth parameters such as plant height, number of leaves, leaf area and above-ground dry weight were estimated at harvest. Physiological parameters such as leaf area ratio, relative growth rate (RGR) and net assimilation rate (NAR) were determined according to Gardner (1985). Marketable fruits were manually harvested at intervals of 3 days starting from 10 WAT for Roma V.F. and 11 WAT for Tropimech for yield estimation. The number of fruit per plant and fruit weight in $1 \mathrm{~m}^{2}$ area and harvest index were also estimated.

\section{(b) Fruit Quality and Proximate Composition}

The $\mathrm{pH}$ and titratable acidity of the fruits were determined. The ascorbic acid of the fruit was determined according to Association of Official Analytical Chemist (AOAC, 1980) titrimetric method using 2,6-Dichlorophenol indophenol (DCPIP). To achieve this, $5 \mathrm{~g}$ of each sample was weighed and macerated in 15 $\mathrm{ml}$ metaphosphoric glacial acetic acid mixture in a beaker containing $1.0 \mathrm{~g}$ activated charcoal. The resulting mixture was boiled for ten minutes and thereafter filtered with Wattman No. 1 filter paper in a conical flask. For complete extraction of the vitamin C, $10 \mathrm{ml}$ of metaphosphoric glacial acetic acid was added. Distilled water was added to each conical flask and made the volume up to $100 \mathrm{ml}$. A blank solution was titrated with 2,6-Dichlorophenol indophenol dye in a beaker until pink colour was obtained. The quantity used to achieve the end point was recorded. The ascorbic acid was calculated as: $\mathrm{mg}$ ascorbic acid/g sample $=\mathrm{V} \times \mathrm{S} \times \mathrm{D}$.

Where $\mathrm{V}=$ Volume of dye used to titrate, $\mathrm{S}=$ Standardization value in $\mathrm{mg}$ ascorbic acid and $\mathrm{D}=$ dilution factor. It should be noted that each of the foregoing was done in three replicates.

The ripen tomato fruits were analysed for lycopene and $\beta$-carotene contents simultaneously following the methods of Nagata and Yamahita (1992). One grams of ripen tomato was homogenized in a test tube containing $20 \mathrm{ml}$ acetone-hexane mixture in the ratio of 4:6. The acetone-hexane mixture assist in the separation of the pigments. Measurement of the absorbance was read at $663,645,505$ and $453 \mathrm{~nm}$ at the same time. The absorbencies at these wave lengths were used to estimate lycopene and $\beta$-carotene using the equations depicted below:

Lycopene $=-0.0458 \mathrm{~A}+0.204 \mathrm{~A}_{645}+0.372 \mathrm{~A}_{505}$ $0.0806 \mathrm{~A}_{453}$

$\beta$-carotene $=0.216 \mathrm{~A}_{663}-1.22 \mathrm{~A}_{645}-0.304 \mathrm{~A}_{505}+$ $0.452 \mathrm{~A}_{453}$ 
Proximate composition of the fresh fruits (moisture, ash, fibre, protein, fat and carbohydrate) was determined following the method described by AOAC (2000).

\section{Data analysis}

The data recorded from the two locations were pooled together on account of non-significant interaction between location, treatment and varieties. Treatment means were separated using least significant difference (LSD) at 0.01 probability level.

\section{RESULTS AND DISCUSSION}

\section{Weed Flora Composition}

A total of 14 weed species were encountered at the experimental site (Table 01).The preponderant weed species encountered were broad-leaved weeds (dicot). These broadleaved weeds were mostly annual species and they were greater in number than annual and perennial grasses (Table 01). This scenario was due to lack of satisfactory weed control either from hand weeding and sole herbicide application. Similar results had been reported by Hakim et al. (2010) in their studies of distribution of weed species in the rice growing area in Malaysia. The most represented families were Asteraceae, Euphorbiaceae and Poaceae (Table 01). Earlier studies have revealed that the vegetation of a particular area is determined not only by environment but also by edaphic, biological factors, $\mathrm{pH}$, nutrients, moisture status, associated crop and weed control measures (Kim et al., 1983). Considering the frequencies among the encountered weed species, Euphorbia heterophylla was the most common followed by Tridax procumbens, Tithonia diversifolia, Phyllantus amarus, Gomphrena celosioides, and Ageratum conyzoide. These weed species have been reported to be preponderant in tomato fields (Awodoyin et al, 2007; Adesina et al., 2014).

\section{Weed Control Effort}

Weed biomass, weed control efficiency and weed index were significantly $(p<0.01)$ affected by the weed control methods (Table 02). Weed free check recorded significantly $(p \leq 0.01)$ higher weed biomass with values of $71.17 \mathrm{~g} \mathrm{~m}^{-2}$ and $69.84 \mathrm{gm}^{-2}$ in Roma V.F. and Tropimech respectively. Treatments such as Pendimethalin at $41 \mathrm{ha}^{-1}+$ one hand weeding at 6 WAP, two hand weeding at 3 and 6 WAP had significantly lower weed biomasses compared to sole application of Pendimethalin at $4 \mathrm{lha}^{-1}$ (Table 02). Weed free check recorded significantly higher weed control efficiency in both varieties (96.23\% and $98.78 \%$ ) followed by Pendimethalin at $4 \mathrm{lha}^{-1}+$ one hand weeding at 6 WAP, two hand weeding at 3 and $6 \mathrm{WAP}$, and Pendimethalin at $4 \mathrm{lha}^{-1}$ (Table 02). Weedy check recorded significantly lower weed control efficiency over all other treatments. Weed index values were lower in weed control treatments. A significantly higher weed index was recorded in weedy check $(59.25 \%$ and $84.44 \%$ ) over all the other treatments (Table 02). The results were in conformity with earlier findings where higher weed biomass was linked to zero weed control measure on weed growth (Olayinka and Etejere, 2015; Muhammad et al., 2016). The lowest weed control efficiency recorded in sole Pendimethalin at $4 \mathrm{lha}^{-1}$ when compared to treatment such as two hand weeding at 3 and 6 WAT and Pendimethalin at $41 \mathrm{ha}^{-1}+$ one hand weeding at 6 WAT was due to inability of the herbicide to provide continuous weed control. This scenario had been observed by Akobundu (1987) and other researchers such as Olorunmaiye and Olorunmaiye (2009) and Olayinka and Etejere (2015) in their studies of weed control methods in arable crops. 
Table 01: Weed species of the experimental plot and their relative abundance frequency under weed control methods in tomato (pooled data of two cropping locations in 2015).

\begin{tabular}{clccc}
\hline S/N & \multicolumn{1}{c}{ Weed species } & Life cycle & Relative abundance (\%) & Family \\
\hline 1 & Ageratum conyzoides Linn. & ABL & 10.16 & Asteraceae \\
2 & Crotalaria retusaLinn. & ABL & 3.35 & Fabaceae \\
3 & Cochorus olitorus Linn. & ABL & 3.14 & Malvaceae \\
4 & CommelinaerectaJ.K. Morton & PBL & 3.70 & Commelinaceae \\
5 & Euphorbia heterophyllaLinn. & ABL & 14.65 & Euphorbiaceae \\
6 & Gomphrenacelosioides Mart. & ABL & 11.47 & Amaranthaceae \\
7 & Impereta cylindrica (Linn.)C.E. Hubbard & PG & 0.77 & Poaceae \\
8 & Mitracarpus villosus (Sw.) DC. & ABL & 3.61 & Rubiaceae \\
9 & Phyllantus amarusSchum.and Thonn. & ABL & 13.69 & Euphorbiaceae \\
10 & Seteria pumila (Poir.) RoemandSchult & AG & 3.64 & Poaceae \\
11 & Talinum triangulare (Jacq.)Willd. & PBL & 1.48 & Portulacaceae \\
12 & Tithoniadiversifolia (Hemsl.)A. Gray & ABL & 12.18 & Asteraceae \\
13 & Tridax procumbens Linn. & ABL & 14.33 & Asteraceae \\
14 & Vernonia cinerea (Linn.) Less. & ABL & 5.40 & Asteraceae \\
\hline
\end{tabular}

Key: 9.3\% and above = Very abundant; 4.6-9.2\%=abundant $\leq 4.5 \%=$ less abundant. PBL (Perennial broad leaved) ABL (Annual broad leaved), AG (Annual grass); PG (perennial grass)

Table 02: Weed biomass, weed control efficiency and weed index in Roma V.F. and Tropimech as affected by weed control methods (pooled data of two cropping locations in 2015).

\begin{tabular}{|c|c|c|c|c|}
\hline Variety & Treatment & Weed biomass $\left(\mathrm{gm}^{-2}\right)$ & Weed control efficiency $(\%)$ & Weed Index $(\%)$ \\
\hline \multirow{6}{*}{ Roma V.F. } & $\mathrm{T}_{1}$ & $35.42^{b}$ & $40.87^{\mathrm{c}}$ & $43.47^{\mathrm{ab}}$ \\
\hline & $\mathrm{T}_{2}$ & $26.29^{c}$ & $63.79^{b}$ & $14.54^{\mathrm{c}}$ \\
\hline & $\mathrm{T}_{3}$ & $32.64^{b}$ & $53.35^{\mathrm{b}}$ & $33.40^{\mathrm{b}}$ \\
\hline & $\mathrm{T}_{4}$ & $1.40^{\mathrm{d}}$ & $96.23^{\mathrm{a}}$ & $0.00^{\mathrm{d}}$ \\
\hline & $\mathrm{T}_{5}$ & $71.74^{\mathrm{a}}$ & $0.00^{\mathrm{d}}$ & $59.25^{\mathrm{a}}$ \\
\hline & Mean & 41.3.2 & 52.67 & 35.70 \\
\hline \multirow{7}{*}{ Tropimech } & $\mathrm{T}_{1}$ & $47.587^{b}$ & $31.81^{\mathrm{c}}$ & $42.02^{b}$ \\
\hline & $\mathrm{T}_{2}$ & $22.07^{\mathrm{d}}$ & $68.39^{\mathrm{b}}$ & $16.91^{\mathrm{c}}$ \\
\hline & $\mathrm{T}_{3}$ & $32.49^{c}$ & $53.53^{c}$ & $36.31^{\mathrm{b}}$ \\
\hline & $\mathrm{T}_{4}$ & $1.23^{\mathrm{e}}$ & $98.78^{\mathrm{a}}$ & $0.00^{\mathrm{d}}$ \\
\hline & $\mathrm{T}_{5}$ & $69.84^{\mathrm{a}}$ & $0.00^{\mathrm{d}}$ & $84.44^{\mathrm{a}}$ \\
\hline & Mean & 42.96 & 51.34 & 44.92 \\
\hline & Grand mean & 42.16 & 52.01 & 40.31 \\
\hline \multirow{3}{*}{$\operatorname{LSD}(p<0.01)$} & Variety & 14.39 & 20.55 & 15.57 \\
\hline & Treatments & 8.79 & 10.17 & 16.76 \\
\hline & $\mathrm{V} \times \mathrm{T}$ & 4.36 & 7.29 & 2.65 \\
\hline
\end{tabular}

Values followed by the same superscripts along the column are significantly the same at $\mathrm{p} \leq 0.01 . \mathrm{T}_{1}$ Pendimethalin at $4 \mathrm{lha}^{-1} ; \mathrm{T}_{2}=$ Pendimethalin at $4 \mathrm{lha}^{-1}+$ one hand weeding at $6 \mathrm{WAP} ; \mathrm{T}_{3}=$ Two hand weeding at 3 and $6 \mathrm{WAP} ; \mathrm{T}_{4}=$ Weed free check (Positive control); $\mathrm{T}_{5}=$ Weedy check (negative control). 


\section{Growth Response}

In both varieties plant height, the number of leaves, leaf area and above-ground dry weight at harvest were significantly $(p<0.01)$ increased by weed control methods (Table 03). These growth attributes were significantly lower in weedy check when compared to other treatments. The enhanced growth attributes recorded from the weed free check, Pendimethalin at $4 \mathrm{ha}^{-1}+$ one hand weeding at 6 WAP, two hand weeding at 3 and 6 WAT over sole Pendimethalin at 4lha ${ }^{1}$ and weedy check could be attributed to low incidence of weeds interference. The results agreed with the studies of Madueke (2010), Madukwe et al.(2012), Imoloame et al. (2014) who had variously reported better growth in all the weed control treatments than the weedy check most importantly where chemical was combined with one hand weeding. Weeds have generally be known to compete with crop for resources that are necessary for plant growth and developments (El-Naim, et al., 2010).

\section{Physiological Response}

Leaf area ratio at 6, 9 and 12 WAT in Roma V.F. and Tropimech varied significantly $(\mathrm{p}<0.01)$ due to weed control methods (Table 04). At 6 WAT the weed free check till harvest recorded significantly highest leaf area ratio followed by Pendimethalin at $4 \mathrm{lha}^{-1}+$ one hand weeding at 6 WAP, two hand weeding at 3 and 6 WAT and sole Pendimethalin at 4lha ${ }^{-1}$. (Table 04). Minimum leaf area ratio was recorded under the weedy check. A similar pattern was maintained at 9 WAT except that there was reduction in leaf area ratio. The leaf area ratio was further declined at 12 WAT in all the treatments. A reduction in leaf area with age has been observed as a feature in annual plants (Adeyemi, 1999, Olayinka et al., 2009). Relative growth and net assimilation followed similar pattern as recorded for leaf area ratio as they were enhanced in all the weed control treatments compared to the weedy check (Table 04).

Table 03: Plant height, number of leaves leaf area and above-ground dry weight in Roma V.F. and Tropimech as affected by different weed control methods (pooled data of two cropping locations in 2015).

\begin{tabular}{|c|c|c|c|c|c|}
\hline \multirow{2}{*}{ Variety } & \multirow{2}{*}{ Treatment } & Plant height $(\mathrm{cm})$ & Number of leaves & Leaf area $\left(\mathrm{m}^{2}\right)$ & Above-ground dry weight (g) \\
\hline & & \multicolumn{4}{|c|}{ At harvest } \\
\hline \multirow{6}{*}{ Roma V.F. } & $\mathrm{T}_{1}$ & $59.13^{\mathrm{d}}$ & $31.66^{\mathrm{d}}$ & $6.53^{\mathrm{d}}$ & $8.64^{\mathrm{c}}$ \\
\hline & $\mathrm{T}_{2}$ & $61.11^{c}$ & $32.67^{\mathrm{c}}$ & $7.15^{\mathrm{b}}$ & $9.18^{\mathrm{ab}}$ \\
\hline & $\mathrm{T}_{3}$ & $61.13^{\mathrm{b}}$ & $32.11^{\mathrm{b}}$ & $6.89^{\mathrm{c}}$ & $8.80^{\mathrm{ab}}$ \\
\hline & $\mathrm{T}_{4}$ & $65.33^{\mathrm{a}}$ & $33.33^{\mathrm{a}}$ & $7.30^{\mathrm{a}}$ & $10.41^{\mathrm{a}}$ \\
\hline & $\mathrm{T}_{5}$ & $47.40^{\mathrm{e}}$ & $21.11^{\mathrm{e}}$ & $3.79^{\mathrm{e}}$ & $7.45^{\mathrm{d}}$ \\
\hline & Mean & 58.82 & 30.15 & 6.26 & 8.90 \\
\hline \multirow{7}{*}{ Tropimech } & $\mathrm{T}_{1}$ & $42.43^{\mathrm{d}}$ & $30.33^{c}$ & $4.93^{\mathrm{c}}$ & $5.66^{\mathrm{c}}$ \\
\hline & $\mathrm{T}_{2}$ & $46.76^{\mathrm{b}}$ & $33.33^{\mathrm{b}}$ & $6.66^{\mathrm{b}}$ & $6.58^{\mathrm{b}}$ \\
\hline & $\mathrm{T}_{3}$ & $43.76^{\mathrm{c}}$ & $26.67^{\mathrm{d}}$ & $5.52^{\mathrm{d}}$ & $6.19^{\mathrm{bc}}$ \\
\hline & $\mathrm{T}_{4}$ & $49.53^{\mathrm{a}}$ & $35.67^{\mathrm{a}}$ & $7.54^{\mathrm{a}}$ & $8.65^{\mathrm{a}}$ \\
\hline & $\mathrm{T}_{5}$ & $36.43^{\mathrm{e}}$ & $28.67^{\mathrm{e}}$ & $3.89^{\mathrm{e}}$ & $4.39^{\mathrm{d}}$ \\
\hline & Mean & 43.78 & 30.93 & 5.61 & 6.29 \\
\hline & Grand mean & 51.30 & 30.54 & 5.94 & 7.60 \\
\hline \multirow{3}{*}{$\begin{array}{c}\text { LSD } \\
(\mathrm{p}<0.01)\end{array}$} & Variety & 2.30 & 0.03 & 1.17 & 4.42 \\
\hline & Treatments & 3.45 & 1.12 & 0.15 & 1.53 \\
\hline & $\mathrm{V} \times \mathrm{T}$ & 5.78 & 7.89 & 1.11 & 4.18 \\
\hline
\end{tabular}

Values followed by the same superscripts along the column are significantly the same at $\mathrm{p} \leq 0.05 . \mathrm{T}_{1=}$ Pendimethalin at 4 lha ${ }^{-1} ; \mathrm{T}_{2}=$ Pendimethalin at $4 \mathrm{lha}^{-1}+$ one hand weeding at $6 \mathrm{WAP} ; \mathrm{T}_{3}=$ Two hand weeding at 3 and $6 \mathrm{WAP} ; \mathrm{T}_{4}=$ Weed free check (Positive control); $\mathrm{T}_{5}=$ Weedy check (negative control) 
Table 04: Leaf area ratio, relative growth rate and net assimilation rate as affected by different weed control methods (pooled data of two cropping locations in 2015)

\begin{tabular}{|c|c|c|c|c|c|c|c|c|c|c|}
\hline \multirow{3}{*}{ Variety } & \multirow{3}{*}{ Treatment } & \multicolumn{3}{|c|}{$\begin{array}{l}\text { Leaf area ratio } \\
\qquad\left(\mathrm{m} \mathrm{g}^{-1}\right)\end{array}$} & \multicolumn{3}{|c|}{$\begin{array}{l}\text { Relative growth rate } \\
\qquad\left(\mathrm{g} \mathrm{g}^{-1} \text { day }^{-1}\right)\end{array}$} & \multicolumn{3}{|c|}{$\begin{array}{l}\text { Net assimilation rate } \\
\qquad\left(\mathrm{g} \mathrm{m}^{-2} \text { day }^{-1}\right)\end{array}$} \\
\hline & & \multicolumn{9}{|c|}{ Weeks After Sowing } \\
\hline & & 6 & 9 & 12 & $3-6$ & $6-9$ & $9-12$ & $3-6$ & 6-9 & $9-12$ \\
\hline \multirow{6}{*}{ Roma V.F. } & $\mathrm{T}_{1}$ & $1.09^{\mathrm{e}}$ & $1.01^{\mathrm{d}}$ & $0.79^{\mathrm{d}}$ & $0.0058^{\mathrm{b}}$ & $0.0039^{\mathrm{c}}$ & $0.0022^{\mathrm{a}}$ & $0.0061^{\mathrm{a}}$ & $0.0046^{\mathrm{b}}$ & $0.0030^{\mathrm{a}}$ \\
\hline & $\mathrm{T}_{2}$ & $1.16^{\mathrm{d}}$ & $1.06^{\mathrm{b}}$ & $0.90^{\mathrm{a}}$ & $0.0063^{\mathrm{b}}$ & $0.0054^{\mathrm{c}}$ & $0.0033^{\mathrm{d}}$ & $0.0049^{\mathrm{c}}$ & $0.0046^{\mathrm{b}}$ & $0.0013^{\mathrm{c}}$ \\
\hline & $\mathrm{T}_{3}$ & $1.18^{\mathrm{c}}$ & $1.11^{\mathrm{a}}$ & $0.66^{\mathrm{b}}$ & $0.0053^{\mathrm{c}}$ & $0.0043^{\mathrm{b}}$ & $0.0027^{\mathrm{d}}$ & $0.0044^{\mathrm{d}}$ & $0.0041^{\mathrm{c}}$ & $0.0014^{c}$ \\
\hline & $\mathrm{T}_{4}$ & $1.21^{\mathrm{a}}$ & $1.02^{\mathrm{c}}$ & $0.82^{\mathrm{c}}$ & $0.0063^{\mathrm{a}}$ & $0.0048^{\mathrm{a}}$ & $0.0041^{\mathrm{b}}$ & $0.0057^{\mathrm{b}}$ & $0.0048^{\mathrm{a}}$ & $0.0027^{\mathrm{b}}$ \\
\hline & $\mathrm{T}_{5}$ & $1.04^{\mathrm{b}}$ & $0.95^{\mathrm{e}}$ & $0.89^{\mathrm{e}}$ & $0.0053^{\mathrm{d}}$ & $0.0028^{\mathrm{d}}$ & $0.0019^{c}$ & $0.0033^{\mathrm{e}}$ & $0.0036^{\mathrm{d}}$ & $0.0027^{\mathrm{b}}$ \\
\hline & Mean & 1.14 & 1.03 & 0.81 & 0.0058 & 0.0042 & 0.0028 & 0.0048 & 0.0044 & 0.0022 \\
\hline \multirow{7}{*}{ Tropimech } & $\mathrm{T}_{1}$ & $0.79^{\mathrm{c}}$ & $1.19^{\mathrm{d}}$ & $1.04^{\mathrm{a}}$ & $0.0044^{\mathrm{c}}$ & $0.0047^{\mathrm{d}}$ & $0.0023^{\text {bc }}$ & $0.0011^{\mathrm{d}}$ & $0.0035^{b}$ & $0.0034^{b}$ \\
\hline & $\mathrm{T}_{2}$ & $0.88^{\mathrm{b}}$ & $1.22^{\mathrm{c}}$ & $1.00^{\mathrm{d}}$ & $0.0060^{\mathrm{a}}$ & $0.0052^{\mathrm{a}}$ & $0.0013^{\mathrm{c}}$ & $0.0014^{\mathrm{c}}$ & $0.0061^{\mathrm{a}}$ & $0.0031^{\mathrm{c}}$ \\
\hline & $\mathrm{T}_{3}$ & $0.80^{\mathrm{d}}$ & $1.34^{\mathrm{b}}$ & $0.80^{\mathrm{c}}$ & $0.0059^{\mathrm{b}}$ & $0.0047^{\mathrm{c}}$ & $0.0017^{\mathrm{ab}}$ & $0.0013^{\mathrm{c}}$ & $0.0048^{\mathrm{d}}$ & $0.0034^{\mathrm{b}}$ \\
\hline & $\mathrm{T}_{4}$ & $0.90^{\mathrm{a}}$ & $1.50^{\mathrm{a}}$ & $1.02^{\mathrm{b}}$ & $0.0074^{\mathrm{a}}$ & $0.0054^{\mathrm{b}}$ & $0.0021^{\mathrm{a}}$ & $0.0018^{\mathrm{b}}$ & $0.0029^{\mathrm{d}}$ & $0.0051^{\mathrm{a}}$ \\
\hline & $\mathrm{T}_{5}$ & $0.78^{\mathrm{e}}$ & $1.10^{\mathrm{e}}$ & $1.01^{\mathrm{e}}$ & $0.0040^{\mathrm{c}}$ & $0.0032^{\mathrm{e}}$ & $0.0012^{\mathrm{c}}$ & $0.0053^{\mathrm{a}}$ & $0.0030^{\mathrm{c}}$ & $0.0032^{\mathrm{c}}$ \\
\hline & Mean & 0.83 & 1.26 & 0.97 & 0.0055 & 0.0047 & 0.0017 & 0.0022 & 0.0041 & 0.0036 \\
\hline & Grand mean & 0.98 & 1.15 & 0.89 & 0.0057 & 0.0045 & 0.0023 & 0.0035 & 0.0042 & 0.0029 \\
\hline \multirow{3}{*}{$\begin{array}{c}\text { LSD } \\
(p<0.01)\end{array}$} & Variety & 0.003 & 0.023 & 0.003 & 0.0023 & 0.0011 & 0.0023 & 0.0023 & 0.0016 & 0.0024 \\
\hline & Treatments & 0.001 & 0.013 & 0.001 & 0.0003 & 0.0031 & 0.0013 & 0.0003 & 0.0001 & 0.0007 \\
\hline & $\mathrm{V} \times \mathrm{T}$ & 0.002 & 0.012 & 0.012 & 0.0002 & 0.0006 & 0.0024 & 0.0002 & 0.0002 & 0.0004 \\
\hline
\end{tabular}

Values followed by the same superscripts along the column are significantly the same at $\mathrm{p} \leq 0.05 . \mathrm{T}_{1=}$ Pendimethalin at $4 \mathrm{lha}^{-1} ; \mathrm{T}_{2}=$ Pendimethalin at $4 \mathrm{lha}^{-1}+$ one hand weeding at $6 \mathrm{WAP} ; \mathrm{T}_{3}=$ Two hand weeding at 3 and $6 \mathrm{WAP} ; \mathrm{T}_{4}=$ Weed free check (Positive control); $\mathrm{T}_{5}=$ Weedy check (negative control).

This showed that growth of tomato was grossly affected in weedy check situation on account of heavy weed infestation. The higher RGR and NAR in treatments such as Pendimethalin at $41 \mathrm{ha}^{-1}+$ one hand weeding at 6 WAT, two hand weeding at 3 and 6 WAT over sole Pendimethalin could be due to effective weed control provided by these treatments which translate to higher photosynthetic efficiency for increased biomass production. Olayinka and Etejere (2015) had reported similar results in their studies of weed control methods in groundnut. Singh (2004) had observed that photosynthetic rate of leaves decreased as the relative water contents and water potential decreases. The decline in RGR and NAR of tomato towards physiological maturity could be due shading of lower leaves by upper leaves, increase in the number of old leaves with low photosynthetic efficiency (Banik et al., 2009).

\section{Yield}

The different weed control treatments significantly $(p<0.01)$ affect the number of matured fruit per plant and marketable fruit weight and harvest index (Table 05). The weed infestation in weedy check markedly reduced the number and fresh weight of fruit when compared with other weed control treatments (Table 5). Ghohsen et al. (1992) had reported a reduced number of harvested fruits from weedy check with high weed density in tomato. Sole Pendimetalin at $4 \mathrm{lha}^{-1}$ showed yield that was statistically lower compared to Pendimnthalin at $4 \mathrm{lha}^{-1}+$ one hand weeding at 6 WAT and two hand weeding at 3 and 6 WAT. Aside from the weed free check that recorded maximum yield, Pendimnthalin at $4 \mathrm{lha}^{-1}+$ one hand weeding at 6 WAT favoured higher yield when compared to other weed control treatments (Table 5). The enhanced yield in Pendimnthalin at $4 \mathrm{lha}^{-1}+$ one 
hand weeding at 6 WAT treated plots could be attributed to low weed infestation and higher weed control efficiency. These conditions could have in turn provided the tomato plants receiving this treatment greater photosynthetic rate and partitioning of resources into fruit development. Evidence in support of this explanation was found in higher number of harvested fruits and weight of the fruit and a higher harvest index. Madueke et al. (2012) had reported increased yield from weed free check and herbicide + one hand weeding in Tomato. Regardless of weed control methods, yield was higher in Roma V.F. than Tropimech. This could be attributed to differences in gene composition (Hernandez et al., 2008; Olayinka and Etejere, 2015).

\section{Fruit Quality and Proximate Composition}

Weed control methods significantly influenced $(p<0.01)$ the fruit quality assessed in both varieties (Table 06). Varietal differences showed fruits' quality and nutritional compounds assessed were higher in Tropimech than Roma V.F. except pH (Tables 06 and 07).The composition of the tomato fruits aside from fibre and other fruit quality attributes such as $\beta$-carotene, lycopene and vitamin $\mathrm{C}$ contents were generally enhanced in all the weed control treatments compared to the weedy check (Tables 6 and 7). Sole Pendimethalin at $41 \mathrm{ha}^{-1}$ followed by Pendimnthalin at $41 \mathrm{ha}^{-1}+$ one hand weeding at $6 \mathrm{WAP}$ had positive influence on the fruit quality of tomato. Engelmann et al. (2009) had found that herbicides increased lycopene and quality of carotenoid in tomato. Generally, proximate composition and biochemical constituents were higher in Tropimech than Roma V.F. Differential gene composition could account for this observed difference. The bulk of tomato contained moisture. This explained why the crop had low shelf life (Onifade et al., 2013). The low fat content of the two varieties make tomato a good diet for heart diseases. The $\beta$-carotene, lycopene and vitamin $\mathrm{C}$ were respectively higher in all the weed control treatments compared to the weedy check. This showed that reduction of weed infestation have marked influence on the antioxidant contents of tomato.

Table 05: Number of fruit per plant, fresh weight of fruit and harvest index as affected by different weed control methods (pooled data of two cropping locations in 2015)

\begin{tabular}{|c|c|c|c|c|}
\hline Variety & Treatment & Number of fruit per plant & Fresh weight of fruit $\left(\mathrm{g} \mathrm{m}^{-2}\right)$ & Harvest Index (\%) \\
\hline \multirow{6}{*}{ Roma V.F. } & $\mathrm{T}_{1}$ & $15.00^{\mathrm{c}}$ & $35.75^{\mathrm{c}}$ & $73.67^{\mathrm{c}}$ \\
\hline & $\mathrm{T}_{2}$ & $24.67^{\mathrm{a}}$ & $54.6^{\mathrm{b}}$ & $81.67^{\mathrm{a}}$ \\
\hline & $\mathrm{T}_{3}$ & $19.0^{\mathrm{bc}}$ & $46.58^{\mathrm{c}}$ & $76.66^{\mathrm{b}}$ \\
\hline & $\mathrm{T}_{4}$ & $27.33^{\mathrm{ab}}$ & $62.58^{\mathrm{a}}$ & $87.01^{\mathrm{a}}$ \\
\hline & $\mathrm{T}_{5}$ & $7.33^{\mathrm{d}}$ & $14.44^{\mathrm{d}}$ & $62.02^{\mathrm{c}}$ \\
\hline & Mean & 17.87 & 48.98 & 76.2 \\
\hline \multirow{7}{*}{ Tropimech } & $\mathrm{T}_{1}$ & $16.00^{\mathrm{ab}}$ & $20.84^{b}$ & $80.67^{\mathrm{a}}$ \\
\hline & $\mathrm{T}_{2}$ & $20.00^{\mathrm{a}}$ & $37.01^{\mathrm{b}}$ & $80.78^{\mathrm{a}}$ \\
\hline & $\mathrm{T}_{3}$ & $17.33^{\mathrm{a}}$ & $23.68^{b}$ & $81.61^{\mathrm{a}}$ \\
\hline & $\mathrm{T}_{4}$ & $20.67^{\mathrm{a}}$ & $45.37^{\mathrm{a}}$ & $83.27^{\mathrm{a}}$ \\
\hline & $\mathrm{T}_{5}$ & $9.33^{\mathrm{b}}$ & $8.75^{\mathrm{c}}$ & $59.40^{\mathrm{b}}$ \\
\hline & Mean & 16.2 & 23.01 & 77.14 \\
\hline & Grand mean & 17.04 & 36.00 & 76.67 \\
\hline \multirow{3}{*}{$\begin{array}{c}\text { LSD } \\
(\mathrm{p}<0.01)\end{array}$} & Variety & 3.53 & 9.31 & 5.28 \\
\hline & Treatments & 6.12 & 4.35 & 6.81 \\
\hline & $\mathrm{V} \times \mathrm{T}$ & 4.69 & 9.73 & 9.98 \\
\hline
\end{tabular}

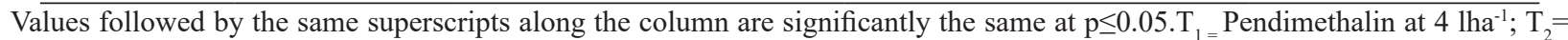
Pendimethalin at $4 \mathrm{lha}^{-1}+$ one hand weeding at $6 \mathrm{WAP} ; \mathrm{T}_{3}=$ Two hand weeding at 3 and $6 \mathrm{WAP} ; \mathrm{T}_{4}=$ Weed free check (Positive control); $\mathrm{T}_{5}=$ Weedy check (negative control). 
Table 06: Fruit quality, vitamin $\mathrm{C}$, lycopene and $\beta$-carotene as affected by weed control methods in two varieties of tomato (pooled data of two cropping locations in 2015).

\begin{tabular}{|c|c|c|c|c|c|c|}
\hline Variety & Treatment & $\mathrm{pH}$ & $\begin{array}{c}\text { Titratable acid } \\
(\%)\end{array}$ & $\begin{array}{l}\text { Vitamin C } \\
(\mathrm{mg} / 100 \mathrm{~g})\end{array}$ & $\begin{array}{l}\text { Lycopene } \\
(\mathrm{mg} / 100 \mathrm{~g})\end{array}$ & $\begin{array}{l}\beta \text {-Carotene } \\
(\mathrm{mg} / 100 \mathrm{~g})\end{array}$ \\
\hline \multirow{6}{*}{ Roma V.F. } & $\mathrm{T}_{1}$ & $4.76^{\mathrm{a}}$ & $0.68^{\mathrm{b}}$ & $28.60^{\mathrm{a}}$ & $5.03^{\mathrm{a}}$ & $0.46^{\mathrm{a}}$ \\
\hline & $\mathrm{T}_{2}$ & $4.71^{\mathrm{a}}$ & $0.70^{\mathrm{b}}$ & $28.37^{\mathrm{b}}$ & $4.89^{\mathrm{a}}$ & $0.41^{b}$ \\
\hline & $\mathrm{T}_{3}$ & $4.96^{\mathrm{a}}$ & $0.48^{\mathrm{d}}$ & $27.92^{\mathrm{c}}$ & $4.55^{b}$ & $0.35^{\mathrm{d}}$ \\
\hline & $\mathrm{T}_{4}$ & $4.82^{\mathrm{a}}$ & $0.52^{\mathrm{c}}$ & $27.58^{\mathrm{d}}$ & $4.00^{c}$ & $0.37^{\mathrm{c}}$ \\
\hline & $\mathrm{T}_{5}$ & $4.84^{\mathrm{a}}$ & $0.72^{\mathrm{a}}$ & $27.18^{\mathrm{e}}$ & $3.86^{\mathrm{c}}$ & $0.31^{\mathrm{e}}$ \\
\hline & Mean & 4.81 & 0.62 & 27.93 & 4.47 & 0.38 \\
\hline \multirow{7}{*}{ Tropimech } & $\mathrm{T}_{1}$ & $4.61^{\mathrm{a}}$ & $0.73^{\mathrm{a}}$ & $31.81^{\mathrm{a}}$ & $5.83^{b}$ & $0.61^{\mathrm{a}}$ \\
\hline & $\mathrm{T}_{2}$ & $4.60^{\mathrm{a}}$ & $0.71^{\mathrm{b}}$ & $30.08^{b}$ & $5.40^{\mathrm{c}}$ & $0.58^{\mathrm{ab}}$ \\
\hline & $\mathrm{T}_{3}$ & $4.63^{\mathrm{a}}$ & $0.64^{c}$ & $29.10^{\mathrm{c}}$ & $4.84^{\mathrm{d}}$ & $0.530^{\mathrm{b}}$ \\
\hline & $\mathrm{T}_{4}$ & $4.82^{\mathrm{a}}$ & $0.65^{\mathrm{c}}$ & $29.58^{\mathrm{c}}$ & $6.11^{\mathrm{a}}$ & $0.53^{\mathrm{b}}$ \\
\hline & $\mathrm{T}_{5}$ & $4.63^{\mathrm{a}}$ & $0.58^{d}$ & $28.13^{\mathrm{d}}$ & $4.06^{\mathrm{e}}$ & $0.44^{\mathrm{c}}$ \\
\hline & Mean & 4.66 & 0.66 & 29.75 & 5.25 & 0.54 \\
\hline & Grand mean & 4.74 & 0.64 & 28.84 & 4.86 & 0.46 \\
\hline \multirow{3}{*}{$\begin{array}{c}\text { LSD } \\
(\mathrm{P}<0.01)\end{array}$} & Variety & 4.03 & 3.82 & 5.39 & 3.22 & 3.45 \\
\hline & Treatment & 2.48 & 0.19 & 3.79 & 3.00 & 0.24 \\
\hline & $\mathrm{V} \times \mathrm{T}$ & 0.41 & 5.23 & 3.62 & 2.83 & 3.58 \\
\hline
\end{tabular}

Values followed by the same superscripts along the column are significantly the same at $\mathrm{p} \leq 0.01 . \mathrm{T}_{1=}$ Pendimethalin at 4 lha $^{-1} ; \mathrm{T}_{2}=$ Pendimethalin at $4 \mathrm{lha}^{-1}+$ one hand weeding at $6 \mathrm{WAP} ; \mathrm{T}_{3}=$ Two hand weeding at 3 and $6 \mathrm{WAP} ; \mathrm{T}_{4}=$ Weed free check (Positive control); $\mathrm{T}_{5}=$ Weedy check (negative control)

Table 07: Composition of the seeds and energy value as affected by weed control methods in two varieties of tomato

\begin{tabular}{|c|c|c|c|c|c|c|c|c|}
\hline Variety & Treatment & $\begin{array}{c}\text { Moisture } \\
(\%)\end{array}$ & $\begin{array}{l}\text { Ash } \\
(\%)\end{array}$ & $\begin{array}{c}\text { Fibre } \\
(\%)\end{array}$ & $\begin{array}{c}\text { Protein } \\
(\%)\end{array}$ & $\begin{array}{l}\text { Fat } \\
(\%)\end{array}$ & $\begin{array}{c}\text { Carbohydrate } \\
(\%)\end{array}$ & $\begin{array}{c}\text { Energy value } \\
\text { (KCal) }\end{array}$ \\
\hline \multirow{6}{*}{ Roma V.F. } & $\mathrm{T}_{1}$ & $92.52^{\mathrm{d}}$ & $1.12^{\mathrm{a}}$ & $0.63^{\mathrm{a}}$ & $1.31^{\mathrm{a}}$ & $2.21^{\mathrm{a}}$ & $2.23^{\mathrm{b}}$ & $30.85^{\mathrm{a}}$ \\
\hline & $\mathrm{T}_{2}$ & $93.51^{\mathrm{d}}$ & $1.06^{\mathrm{b}}$ & $0.53^{\mathrm{b}}$ & $1.11^{\mathrm{ab}}$ & $2.01^{\mathrm{b}}$ & $1.78^{c}$ & $29.68^{a}$ \\
\hline & $\mathrm{T}_{3}$ & $92.52^{c}$ & $1.03^{\mathrm{b}}$ & $0.48^{\mathrm{c}}$ & $0.97^{\mathrm{ab}}$ & $1.89^{\mathrm{c}}$ & $3.01^{\mathrm{a}}$ & $22.04^{b}$ \\
\hline & $\mathrm{T}_{4}$ & $94.39^{b}$ & $0.80^{\mathrm{c}}$ & $0.46^{\mathrm{c}}$ & $0.94^{\mathrm{b}}$ & $1.72^{\mathrm{d}}$ & $1.93^{\mathrm{bc}}$ & $27.68^{\mathrm{a}}$ \\
\hline & $\mathrm{T}_{5}$ & $95.53^{\mathrm{a}}$ & $0.60^{\mathrm{d}}$ & $0.27^{\mathrm{d}}$ & $0.54^{\mathrm{c}}$ & $1.67^{\mathrm{d}}$ & $1.31^{\mathrm{d}}$ & $29.92^{\mathrm{a}}$ \\
\hline & Mean & 93.69 & 0.92 & 0.47 & 0.97 & 1.90 & 2.05 & 28.03 \\
\hline \multirow{7}{*}{ Tropimech } & $\mathrm{T}_{1}$ & $92.38^{\mathrm{bc}}$ & $1.12^{\mathrm{a}}$ & $0.71^{\mathrm{a}}$ & $1.39^{\mathrm{a}}$ & $1.18^{\mathrm{a}}$ & $3.22^{\mathrm{bc}}$ & $29.03^{\mathrm{a}}$ \\
\hline & $\mathrm{T}_{2}$ & $92.76^{\mathrm{b}}$ & $1.01^{\mathrm{b}}$ & $0.68^{\mathrm{ab}}$ & $1.15^{\mathrm{b}}$ & $1.05^{\mathrm{a}}$ & $3.23^{\mathrm{bc}}$ & $27.32^{\mathrm{ab}}$ \\
\hline & $\mathrm{T}_{3}$ & $93.69^{\mathrm{a}}$ & $1.01^{\mathrm{b}}$ & $0.66^{\mathrm{ab}}$ & $1.15^{\mathrm{b}}$ & $1.07^{\mathrm{a}}$ & $2.39^{\mathrm{c}}$ & $23.80^{\mathrm{c}}$ \\
\hline & $\mathrm{T}_{4}$ & $92.34^{\mathrm{bc}}$ & $1.07^{\mathrm{ab}}$ & $0.70^{\mathrm{ab}}$ & $1.06^{\mathrm{bc}}$ & $1.11^{\mathrm{a}}$ & $3.72^{\mathrm{ab}}$ & $29.93^{\mathrm{a}}$ \\
\hline & $\mathrm{T}_{5}$ & $91.98^{c}$ & $0.67^{\mathrm{c}}$ & $0.63^{\mathrm{b}}$ & $0.92^{\mathrm{c}}$ & $0.73^{b}$ & $4.39^{\mathrm{a}}$ & $25.19^{\mathrm{bc}}$ \\
\hline & Mean & 92.63 & 0.98 & 0.68 & 1.14 & 1.03 & 3.39 & 27.05 \\
\hline & Grand mean & 93.16 & 0.95 & 0.58 & 1.06 & 1.47 & 2.72 & 27.54 \\
\hline \multirow{3}{*}{$\begin{array}{c}\text { LSD } \\
(\mathrm{p}<0.01)\end{array}$} & Variety & 2.70 & 10.68 & 4.53 & 2.77 & 1.26 & 7.78 & 15.4 \\
\hline & Treatment & 1.45 & 0.57 & 0.14 & 0.93 & 0.17 & 3.60 & 4.77 \\
\hline & $\mathrm{V} \times \mathrm{T}$ & 1.84 & 1.73 & 3.44 & 1.68 & 0.98 & 0.55 & 8.26 \\
\hline
\end{tabular}

Values followed by the same superscripts along the column are significantly the same at $\mathrm{p} \leq 0.05$. $\mathrm{T}_{1=}$ Pendimethalin at $4 \mathrm{lha}^{-1} ; \mathrm{T}_{2}=$ Pendimethalin at $4 \mathrm{lha}^{-1}+$ one hand weeding at $6 \mathrm{WAP} ; \mathrm{T}_{3}=$ Two hand weeding at 3 and $6 \mathrm{WAP} ; \mathrm{T}_{4}=$ Weed free check (Positive control); $\mathrm{T}_{5}=$ Weedy check (negative control). 


\section{CONCLUSIONS}

Weed control has a significant positive influence on all the tested growth, yield parameters and fruit quality. Pendimethalin does not have continuous weed control ability. It could be needed to be integrated with other weed control methods such as hand weeding as demonstrated in this study to enhance its effectiveness in tomato production.

\section{REFERENCES}

Abbasi, N.A., Zafar, L., Khan H.A. and Qureshi, A.A. (2013). Effects of naphthalene acetic acid and calcium chloride application on nutrient uptake, growth, yield and post harvest performance of tomato fruit. Pakistan Journal of Botany, 45(5): 1581-1587. DOI: http:// dx.doi.org/10.1002/jsfa.7921

Abushita, A.A., Daood, H.G. and Biacs, P.A. (2000). Change in carotenoids and antioxidant vitamins in tomato as a function of varietal and technological factors. Journal of Agricultural and Food Chemistry, 48: 2075-2081. DOI: http://dx.doi.org/10.1021/jf990715p

Adalid, A.M., Rosello S. and Nuez. F. (2004). Breeding tomatoes for their high nutritional value. Rec. Res. Dev. in pl. Sci., 2: 33-52. DOI: http://dx.doi.org/10.17660/actahortic.2008.789.30

Adesina, G.O., Omobolanle, A. O., Ojo, M. A. and Akanbi, W. B (2014). Comparison of Different Composts for Weed Suppression Ability and Tomato Production in Ogbomoso, Nigeria. International Journal of Agriculture and Crop Sciences. 7(9), 569-577. DOI: http://dx.doi. org/10.5897/ajb10.1902

Adeyemi, A. A. (1999). Growth analysis of cocoa (TheobRoma V.F. cacao) under different weed control treatments. Nigerian Journal of Weed Science, 12: 2-7. DOI: http://dx.doi. org/10.21275/v5i5.nov163664

Adigun, J.A. (2000). Chemical weed control in transplanted rainfed tomato (Lycopersicon esculentum Mill) in the forest-savanna. Transition zone of south western Nigeria. Agric. \& Environ., 2(2): 141-150. DOI: http://dx.doi.org/10.4038/tare.v10i0.1871

Agarwal, S. and Rao A.V. (2000). Tomato lycopene and its role in human health and chronic diseases. Canadian Medical Association Journal, 163(6): 739-744. DOI: http://dx.doi. org/10.1089/10966200152053668

Agriexchange (2011). Indian Horticulture Database 2011. Available at http://agriexchange. apeda.gov.in/Market\%20Profile/MOA/Product/Tomato.pdf. DOI: http://dx.doi. org/10.15373/2249555x/may2014/111

Akobundu, I.O. (1987). Weed Science in Tropics: Principles and Practices. New York: John Wiley and Sons. 522pp. DOI: http://dx.doi.org/10.1017/s0014479700016616

Anonymous. (2009). FAOSTAT. www.faostat.fao.org. Retrieved 20/03/2016. DOI: http://dx.doi. org/10.5860/choice.48-2430

Anonymous. (2010). Pakistan Statistical Year Book. Federal Bureau of Statistics. Ministry of Economic Affairs and Statistics, Government of Pakistan. pp. 54-55. DOI: http://dx.doi. org/10.1002/0471667196.ess0332.pub2 
AOAC. (2000). Official Method of Analysis (17th Edition). Volume 1. Association of Official Analytical Chemists. Inc., Maryland, U.S.A. DOI: http://dx.doi.org/10.1002/0471740039. vec0284

Ashton, F. M. and Monaco, F.J. (1991). Weed Science: Principle and Practice. New York: John Willey and Sons Inc. pp. 419. DOI: http://dx.doi.org/10.1017/s0021859600068945

Awodoyin, R.O., Ogbeide, F.I. and Oluwole, O. (2007). Effects of three mulch types on the growth and yield of tomato (Lycopersicon esculentum Mill.) and weed suppression in Ibadan, rainforest-savanna transition zone of Nigeria. Tropical Agricultural Research \& Evaluation, 10: 53-58. DOI: http://dx.doi.org/10.4038/tare.v10i0.1871

Banik, C. N., Nath, R., and Chakraborty, P. K. (2009). Effect of dates of sowing on growth and yield of groundnut crop. Journal of Crop and Weed, 5(2), 59-62. DOI: http://dx.doi.org/10.15740/ has/arjci/6.1/5-11

Binoy, G.K., Charanjit, D., Khurdiya, S. and Kapoor, H.C. (2004). Antioxidants in tomato (Lycopersicum esculentum) as a function of genotype. Food Chemistry, 84: 45-51. DOI: http://dx.doi.org/10.1016/s0308-8146(03)00165-1

El-Naim, A.M., Eldouma, M.A., Ibrahim, E.A. and Zaied, M.M.B. (2011). Influence of plant spacing and weeds on growth and yield of peanut (Arachis hypogaea, L.) in rain-fed of Sudan. Advances in Life Sciences, 1(2): 45-48. DOI: http://dx.doi.org/10.5923/j.als.20110102.08

Engelmann, N.J., Rogers, R.B., Lila, M.A. and Erdman, J.W. (2009). Herbicide treatments alter carotenoid profiles for ${ }^{14} \mathrm{C}$ tracer production from tomato (Solanum lycopersicum cv. VFNT cherry) cell cultures. Journal of Agricultural and Food Chemistry, 57(11): 4614-4619. DOI: http://dx.doi.org/10.1021/jf803905d

FAO (2011). The state of food and agriculture. Women in Agriculture: Closing the Gender Gap for Development. Rome, Italy. Available at http://www.fao.org/docrep/013/i2050e/i20 50e.pdf. DOI: http://dx.doi.org/10.1017/s2078633611000567

Gann, P.H., Ma, J. and Giovannucci, E. (1999). Lower prostate cancer risk in men with elevated plasma lycopene levels: result of a prospective analysis. Cancer Research, 59: 1225-1230. DOI: http://dx.doi.org/10.1093/jnci/94.5.391

Giovannucci, E. (1999). Tomato products, lycopene, and prostate cancer: a review of the epidemiological literature. The Journal of Nutrition, 135(8): 2030-2031. DOI: http://dx.doi. org/10.1093/jnci/91.4.317

Hakim, M.A., Juraimi, A.S., Ismail, M.R., Hanafi, M.M. and Selamat, A. (2010). Distribution of weed population in the coastal rice growing area of Kedah in peninsular Malaysia. Journal of Agronomy, 9(1): 9-16. DOI: http://dx.doi.org/10.3923/ja.2010.9.16

Hernandez, S.M., Rodriguez, E.M., Rodriguez and Diaz R., (2008). Chemical composition of tomato (Lycopersicon esculentum). In: Tenerife, The Canary Islands. Food Chem., 106: 1046-1056. DOI: http://dx.doi.org/10.1016/j.foodchem.2007.07.025 
Imoloame, E.O. (2014). The effect(s) of different weed control methods on weed infestation, growth and yield of soybeans (Glycine max, (L) Merril) in the southern guinea savanna of Nigeria. DOI: http://dx.doi.org/10.4314/agrosh.v14i2.4

Kim, S.C., Park R.K. and Moody, K. (1983). Changes in the weed flora in transplanted rice as affected by introduction of improve rice cultivars and the relationship between weed communities and soil chemical properties. Res. Rept. Ord., 25: 90-97. DOI: http://dx.doi. org/10.1080/09670878909371311

Madukwe, D.K. (2010). Effects of water stress on the nodulation potentials and performance of some legume crops. M.Sc. Thesis Department of Crop Science and Faculty of Agriculture and Veterinary Medicine, Imo State University, Owerri-Nigeria. DOI: http://dx.doi. org/10.18535/ijecs/v4i8.18

Madukwe, D.K., Ogbuehi H.C. and Onuh M. O. (2012). Effects of Weed Control Methods on the Growth and Yield of Cowpea (Vigna unguiculata (L.) Walp) under Rain-Fed Conditions of Owerri. American-Eurasian Journal of Agriculture and Environmental Science, 12(11): 1426-1430. DOI: http://dx.doi.org/10.4314/swj.v3i1.51772

Marana, J., Gongora, R. Paredes, E. and Labrada, R. (1986). Critical period of competition from weeds in direct sown tomatoes. Tech. Agric. Hort., 2(1): 73-83. DOI: http://dx.doi. org/10.1080/09670878309370770

Muhammad, S., Muhammad, I, Sajid, A., Muhammad, I., Maqshoof, A., and Nadeem, A. (2016). The effect of different weed management strategies on the growth and yield of direct-seeded dry rice (Oryza sativa). Planta Daninha, 34(1): 57-64. DOI: http://dx.doi.org/10.1590/ s0100-83582016340100006

Nagata, M. and Yamashita, I. (1992). Simple method for simultaneous determination of chlorophyll and carotenoids in tomato fruit. J. Japan. Soc. Food Sci. Technol., 39(10): 925-928. DOI: http://dx.doi.org/10.3136/nskkk1962.39.925

Olayinka, B. U. and Etejere, E. O. (2015). Growth analysis and yield of two varieties of groundnut (Arachis hypogaea L.) as influenced by different weed control methods. Indian Journal of Plant Physiology, 20(2), 130-136. DOI: http://dx.doi.org/10.1007/s40502-015-0151-x

Olayinka, B.U., Olorunmaiye, K.S. and Etejere, E.O. (2009). Influence of metolachlor on physiological growth character of tomato (Lycopersicon esculentum L.). Ethnobotanical Leaflets, 13: 1288-1294. DOI: http://dx.doi.org/10.5539/mas.v3n3p171

Olorunmaiye, P. M. and Olorunmaiye, K. S. (2009). Effect of integrated weed management on weed control and yield components of maize and cassava intercrop in a southern Guinea savanna ecology of Nigeria. Australian Journal of Crop Science, 3(3), 129-136. DOI: http:// dx.doi.org/10.5251/abjna.2011.2.3.522.528

Onifade, T.B., Aregbesola, O.A., Ige, M.T. and Ajayi A.O. (2013). Some physical properties and thin layer drying characteristics of local varieties of tomatoes (Lycopersicon esculentum). Agriculture and Biology Journal of North America, 4(3): 275-279. DOI: http://dx.doi. org/10.5251/abjna.2013.4.3.275.279 
Tamana, B. and Ijaz, A.K. (2014). Weed control in tomato (Lycopersicon esculentum, Mill.) through mulching and herbicides. Pakistan Journal of Botany, 46(1): 289-292. DOI: http:// dx.doi.org/10.14264/uq1.2016.731

Tesfaye, E., Animut, G., Urge, M. and Dessie, T. (2013). Moringa oleifera leaf meal as an alternative protein feed ingredient in broiler ration. Int. J. Poult. Sci., 12(5): 289-297. DOI: http://dx.doi.org/10.3923/ijps.2013.289.297

Tonucci, L.H., Holden, J.M., Beecher, G.R., Khachik, F., Davis, C.S. and Mulokozi, G. (1995). Carotenoid content of thermally processed tomato-based food-products. Journal of Agricultural and Food Chemistry, 43: 579-586. DOI: http://dx.doi.org/10.1021/jf00051a005 